6. Baltazhi, N. (2018), 100 let otnosheniy Kieva i Sofii. Den [The Day], No. 28-29, p.2, available at: http://m.day.kyiv.ua/ru/article/den-planety/100-let-otnosheniy-kieva-isofii

7. Manasiieva, I. et al. (2019), Ukraina i Bolhariia v istorii Yevropy, [Ukraine and Bulgaria in the history of Europe], Kyiv, Instytut istorii Ukrainy, Ukraine.

8. Perkhavko, V.B. (1984), O torhovykh kontaktakh Kyeva s Bolharyej v IX-XII vv. Problemy sotsyal'no-ekonomycheskoj ystoryy feodal'noj Rossyy [Problems of socioeconomic history of feudal Russia], Moscow, Nauka, USSR.

9. Williamson, J. et al. (1990), Latin American Adjustment. How Much has Happened? Washington, D.C.: Institute for International Economics, The United States.

10. Spisok stran po rostu VVP (PPS) v period s 1990 po 2018 god v protsentah po dannyim WB, available at: https://ru.wikipedia.org/wiki/.

11. Ekonomika Bolgarii: promyishlennost, selskoe hozyaystvo, torgovlya, finansyi, available at: http://www.gecont.ru/articles/econ/bulgar.htm.

12. Mirovoy Atlas Dannyih - Knoema. Ukraina. Vneshnyaya torgovlya. Eksport tovarov i uslug, available at: https://knoema.ru/atlas/\%D0\%A3\%D0\%BA\%D1\% $80 \% \mathrm{D} 0 \% \mathrm{~B} 0 \% \mathrm{D} 0 \% \mathrm{~B} 8 \% \mathrm{D} 0 \% \mathrm{BD} \% \mathrm{D} 0 \% \mathrm{~B} 0$.

13. Embassy of Ukraine in the Republic of Bulgaria. Trade and economic cooperation, available at: https://bulgaria.mfa.gov.ua/.

УДК 314.748 (477)

JEL classification: $\mathrm{C} 51, \mathrm{~F} 22, \mathrm{H} 24, \mathrm{J08}, \mathrm{J18}$

Глущенко Я. I. канд. економ. наук, дочент ORCID ID: 0000-0003-1454-0369

Моісеснко Т. $\mathbf{\epsilon}$. канд. економ. наук, доиент ORCID ID: 0000-0002-2074-8062

Черненко Н. О. канд. економ. наук, доиент ORCID ID: 0000-0002-7424-7829

Національний технічний університет України «Київський політехнічний інститут імені Ігоря Сікорського»

\title{
ВПЛИВ ОПОДАТКУВАННЯ НА РЕГУЛЮВАННЯ МІЖНАРОДНОЇ ТРУДОВОЇ МІГРАЦІї
}

\section{THE IMPACT OF TAXATION ON THE REGULATION OF INTERNATIONAL LABOR MIGRATION}

\footnotetext{
Проведене дослідження обумовлене актуальністю вивчення прочесів трудової міграції, оскільки саме зазначений процес є вагомим фактором впливу на рівень соціального та економічного розвитку держави. Без належного рівня удосконалення економічної, податкової та соціальної політики наслідки міграційних процесів можуть негативно відобразитись на рівні розвитку країни.
} 
Особливі риси міграчійного процесу, а також чинники пов'язані з ним потребують постійного детального вивчення та контролю. У статті запропоновано новий nідхід до теоретичного обтрунтування та вирімення питань трудової міграції, щуо трунтується на встановленні взаємозв'язку між рівнем податкового навантаження країни, а саме таких податків, як: податок на дохід населення та єдиний соиіальний внесок та кількістю ї трудових мігрантів. Для реалізаиї дослідження обрано дві групи країн, щуо є найбільше і найменше привабливими для трудової міграції украӥниів. Результати зазначеної взаємозалежності проілюстровані у вигляді математичної моделі, яка зображена у формі регресії та коефіцієнту апроксимації для прогнозування чисельності мігрантів від показника податкового навантаження. Застосування запропонованої у статті моделі обумовлене необхідністю пошуку оптимальних шляхів зменшення негативного впливу прочесів міжнародної трудової міграчії на рівень економічного та сочіального розвитку краӥни. У статті також визначено перелік залежних від іммігрантів секторів та приділено увагу наслідкам функціонування процесу міграції, а саме ї̈ позитивному впливу. Авторами виокремлено перелік намірів, щуо спонукають громадян до праці за межами Батьківщини, а також встановлено основні фактори, щуо мають суттєвий вилив на характер трудової міграції. Проведене дослідження дозволило авторам зробити припущення про активний характер міграційного руху населення в Україні, а також зростання масштабів зовнішньої трудової міграції та формування потоків вимушеної мігращії, що $\epsilon$ характерними рисами n'ятої хвилі еміграції. Матеріал статті охоплює і перелік основних проблем щзоо регулювання міграції, які уповільнюють прочес співробітництва між Украӥною та країнами ЄС та мають негативні соціальноекономічні наслідки.

Ключові слова: міжнародна міграція, трудові ресурси, регулювання міграційних потоків, міграційний потік, податкове навантаження.

A study in the research paper due the relevance of learning labor migration processes, since this process is a significant factor influencing the level of social and economic development of the state. Without an adequate level of improvement in economic, tax and social policies, the effects of migration can have a negative impact on the level of development of the country. The specific features of the migration process, as well as the factors associated with it, require constant detailed study and control. The article proposes a new approach to the theoretical justification and solution of labor migration issues, based on establishing the relationship between the levels of the tax burden of the country, namely such taxes as: personal income tax and a single social contribution, and the number of its labor migrants. To implement the research results, two groups of countries are identified, - the most and least attractive for labor migration of Ukraine. The conclusions of this mutuality are illustrated in the form of a mathematical model, which is depicted in the form of a regression and an approximation coefficient for predicting the number of migrants of the tax burden indicator. The application of the model that proposed in the article is due to the need to find optimal ways to reduce the negative impact of the international labor migration processes on the economic and social country development level. The article also identifies a list of immigrant-dependent sectors and focuses on the effects of the migration process, namely its positive impact. The authors outline the list of intentions that encourage citizens to work outside their homeland, as well as identify the main factors that have a significant impact on the nature of labor migration. The conducted research allowed the authors to make assumptions about the active nature of the migration movement of the population in Ukraine, as well 
as the increase in the scope of external labor migration and the formation of forced migration flows, which are characteristic features of the fifth wave of emigration. The article also covers a list of major problems in regulating migration, which slow down the process of cooperation between Ukraine and EU countries and have negative socioeconomic consequences.

Keywords: international migration, labor resources, regulation of migration flows, migration flow, tax burden.

Вступ. Процеси трудової міграції в Україні, що є характерними для періоду з 2010 по 2019 рік, істотно відобразились на стані, як соціального, так і економічного розвитку країни. Хоча, обсяг такого впливу на рівні країни лише починає відбиватись на перебігу внутрішньодержавних та зовнішніх процесів, проте, на даний час, вже формується усвідомлення наслідків негативного його впливу. Ігнорування зазначених проблем, що супроводжується відсутністю належних підходів до удосконалення соціальної, економічної політики, а особливо, податкової, - створює додаткові загрози та дисбаланс даних сфер у найближчій перспективі.

Наслідки міжнародної міграції трудових ресурсів є актуальною темою, оскільки, проаналізувавши статистичні дані, можна помітити, що протягом останніх десяти років рівень міграції та кількість мігрантів загалом, мають чітку тенденцію росту, така ситуація вказує на те, що постає необхідність у глибшому науковому та економічному дослідженні поставлених питань. Наслідки від міжнародної міграції трудових ресурсів та її вплив на соціально-економічний розвиток країн розглядали багато вітчизняних та іноземних науковців, таких як $\mathrm{S}$. Castles, M. J. Miller [12], N. Guardia [13], D. Massey [14], О. Дубовий [4], Е. Корчемаха [8], Ю. Курунова [9], О. Пробоїв [11] та інші.

Набуває інтересу той факт, що є значна кількість українців, які шукають вищого рівня доходу (заробітної плати), а не роботу, яку пофакту вони можуть отримати в Україні, проте оплата буде значно меншою. За умови вирівнювання цін в Україні до рівня світових, та підтягування рівня оплати праці у всіх сферах (які відчувають відтік фахівців за кордон) до європейського рівня, це дасть можливість стабілізувати рівень винагороди за працю тих, хто залишатиметься в країні та працюватиме у всіх сферах та галузях. Отже, відповідальність за утримання соціальної сфери та інфраструктури в країні залишається за тими, хто залишається і далі працювати в країні за значно нижчу оплату. Праця кожного офіційно працевлаштованого робітника оподатковується.

Визначення i встановлення оптимального рівня податкового навантаження є важливим для держави, оскільки податки виступають основним джерелом дохідної частини державного бюджету. Надмірне податкове навантаження заробітної плати (а саме податок на доходи 
фізичних осіб, єдиний соціальний внесок, військовий збір) при низькому ії рівні (не вище мінімальної) створює несприятливу ситуацію щодо мотивації українців до праці за таких умов у себе в країні, розпочинається процес пошуку роботи та працевлаштування за кордоном. Надмірний рівень податкового навантаження підприємств, які не застосовують схеми ухилення від оподаткування, призводить до зменшення обсягів їх діяльності, як наслідок скорочення робочих місць, що також стимулює процеси міграції робочої сили. Від'їжджаючи до інших країн («заробітчани» перестають сплачувати податки) державний бюджет недоотримує кошти, уряд держави не спроможний ефективно та в повному обсязі виконувати свої функції, і згодом, змушений шукати шляхи поповнення бюджету, за рахунок збільшення ставок оподаткування, а це у більшій мірі каталізуватиме процес міграції робітників. Отже, визначення оптимального рівня податкового навантаження, який би змусив призупинити «відтік» працюючих $-\epsilon$ складною, проте цікавою проблемою для подальшого дослідження та вирішення.

Постановка завдання. Прогнозування масштабів трудової міграції відповідно до існуючого податкового тягаря $\epsilon$ вагомою складовою у процесі оцінювання демографічної ситуації країни у перспективі, а також таких компонентів, як рівень споживчого попиту та структура зайнятості населення. Міграційні процеси призводять до якісних змін у структурі населення, у свою чергу, важливо акцентувати на тому, що своєчасно сформовані тенденції перебігу процесів трудової міграції, а також прогнозування їх масштабів, сприяє генерації низки ефективних рішень у сфері менеджменту, що, у перспективі, дозволить створити підгрунтя для, більшою мірою, стабільної ситуації на ринку праці в середині країни. Зазначені особливості, створюють умови необхідності визначення ступеня впливу чинників (податковий тягар та рівень ВВП країни), що впливають на прийняття працівником рішення щодо міграції, та побудови моделі для оцінки прогнозних масштабів міжнародної трудової міграції з урахуванням цих чинників.

Методологія. Незважаючи на те, що численні дослідження щодо врегулювання питань міграції проводились та проводяться досить інтенсивно i грунтовно, залишається невирішеними ряд наукових завдань, зокрема не чітко окресленими виявились питання встановлення впливу рівня податків в країні, а саме (податок на дохід населення та єдиний соціальний внесок) на регулювання міжнародної трудової міграції.

Метою статті $є$ формування наукового та методичного підходу до перебігу процесів за обраною тематикою, а також обгрунтування теоретичних аспектів та розробка практичних рекомендацій стосовно проблематики міжнародної міграції, встановлення впливу рівня 
податкового навантаження, як основного економічного фактора, на рівень мігрантів, а також, запропонувати економіко-математичну модель регулювання міжнародних міграційних процесів, що буде містити зазначені залежності, це допоможе зменшити негативний вплив міжнародної трудової міграції на соціально-економічний розвиток країни.

Результати дослідження. Для проведення дослідження авторами обрано країни, які $є$ більшою мірою привабливими для трудової міграції українців, і країни 3 рівнозначними показниками ВВП. До першої групи запропоновано віднести наступні країни: Польща, Російська Федерація, Італія, Греція, Португалія, Іспанія, Німеччина, Чехія. Щодо другої групи, то вважаємо за доцільне включити у дослідження такі країни, як: Болгарія, Естонія, Румунія, Латвія, Литва, Республіка Словенія і Словацька Республіка.

Діаграму чисельності мігрантів досліджуваних країн за 1990 2017 роки представлено на рис.1.

3 представлених на рис.1 країн, одне 3 перших місць за значеннями міграційного потоку займає Російська Федерація. За досліджуваний період міграційний потік РФ змінювався у діапазоні від 11 до 12 млн. осіб. Серед країн із стрімким зростанням показника міграційного потоку за період з 1990 по 2017 рік слід відзначити Іспанію, Італію і Німеччину. Якщо за абсолютним показником лідирує Німеччина, міграційний потік якої був менше 6 млн. осіб у 1990 році, i більше 12 млн. осіб у 2017 році. То, за темпами зростання (2017 p. у порівнянні з 1990 р. на першому місці - Іспанія (656\%), на другому Італія (421\%). [17].

В Україні міграційний потік демонстрував тенденції до зменшення, хоча за рівнем абсолютних значень міграційного потоку наша країна має досить високі значення (1990 р. - 6,9 млн. осіб). Темп зміни міграційного потоку досліджуваних років у порівнянні з 1990 р. мав значення менше 100 \%, стосовно 2017 і 2015 рр. він склав 72 і $71 \%$ відповідно [17]. 


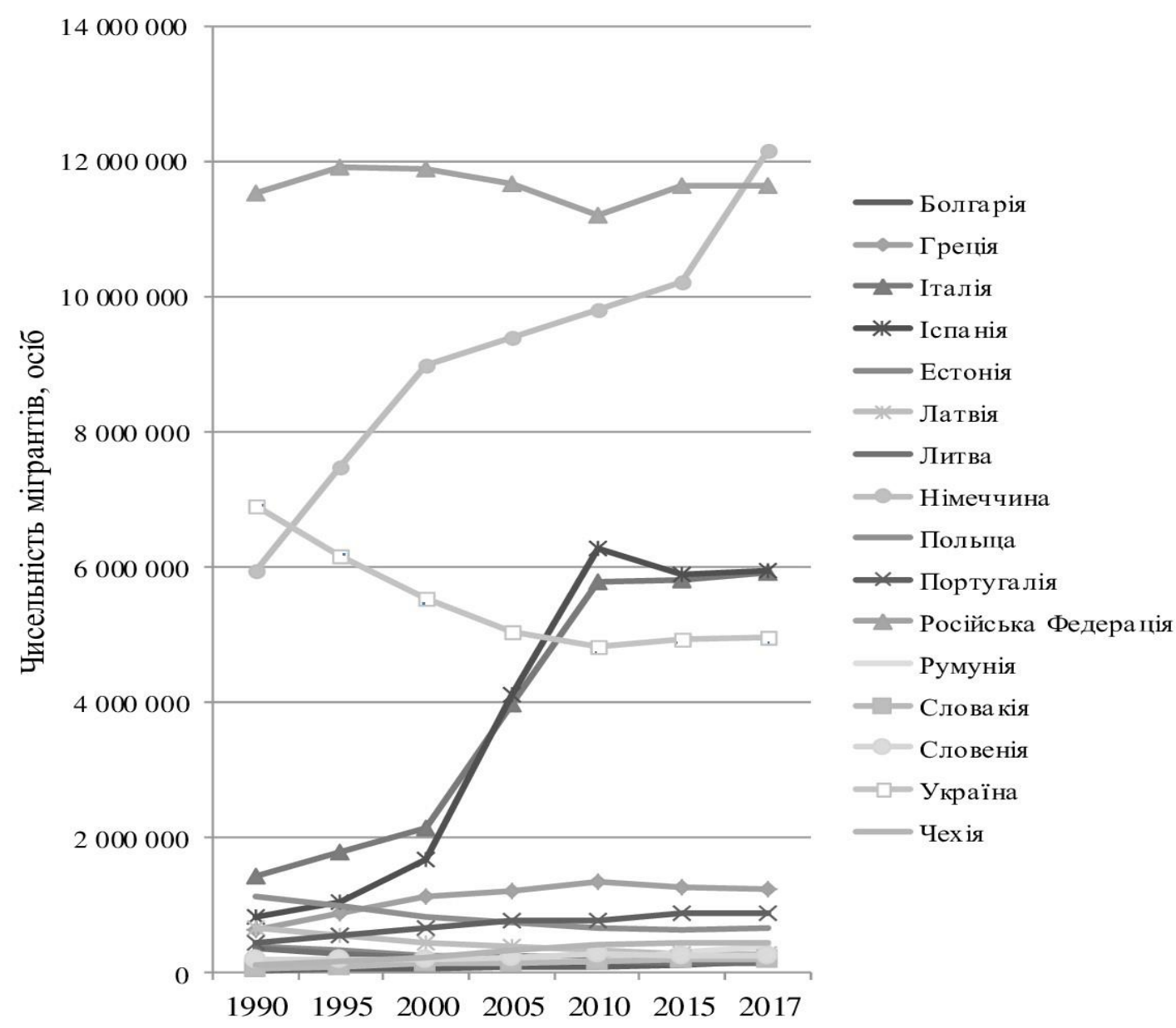

Рисунок 1 - Зміна рівня міграційного потоку України, країн Європи та Російської Федерації за період з 1990 по 2017 pp. Джерело: побудовано на підставі даних [17]

Оцінка динаміки міграційного потоку інших країн, дані яких включено у дослідження, показала, що одні 3 найменших значень абсолютного показника міграційного потоку мають Словацька Республіка, Болгарія. Але, відносні показники міграційного потоку (темпи зміни з базою порівняння 1990 р.), як і в інших країн, мають досить високі значення. Так, наприклад, темп зміни міграційного потоку у 2017 р. Словацької республіки дорівнював 447,1\%, у Болгарії - 715\%. С країни темпи зміни міграційного потоку яких у 2017 р. у порівнянні з 1990 р. значно менше 100\%: Литва - 35,7\%, Естонія $50,5 \%$.

Для більш об'єктивної оцінки міграційної ситуації розглянемо показник співвідношення міграційного потоку і чисельності населення по досліджуваним країнам. 


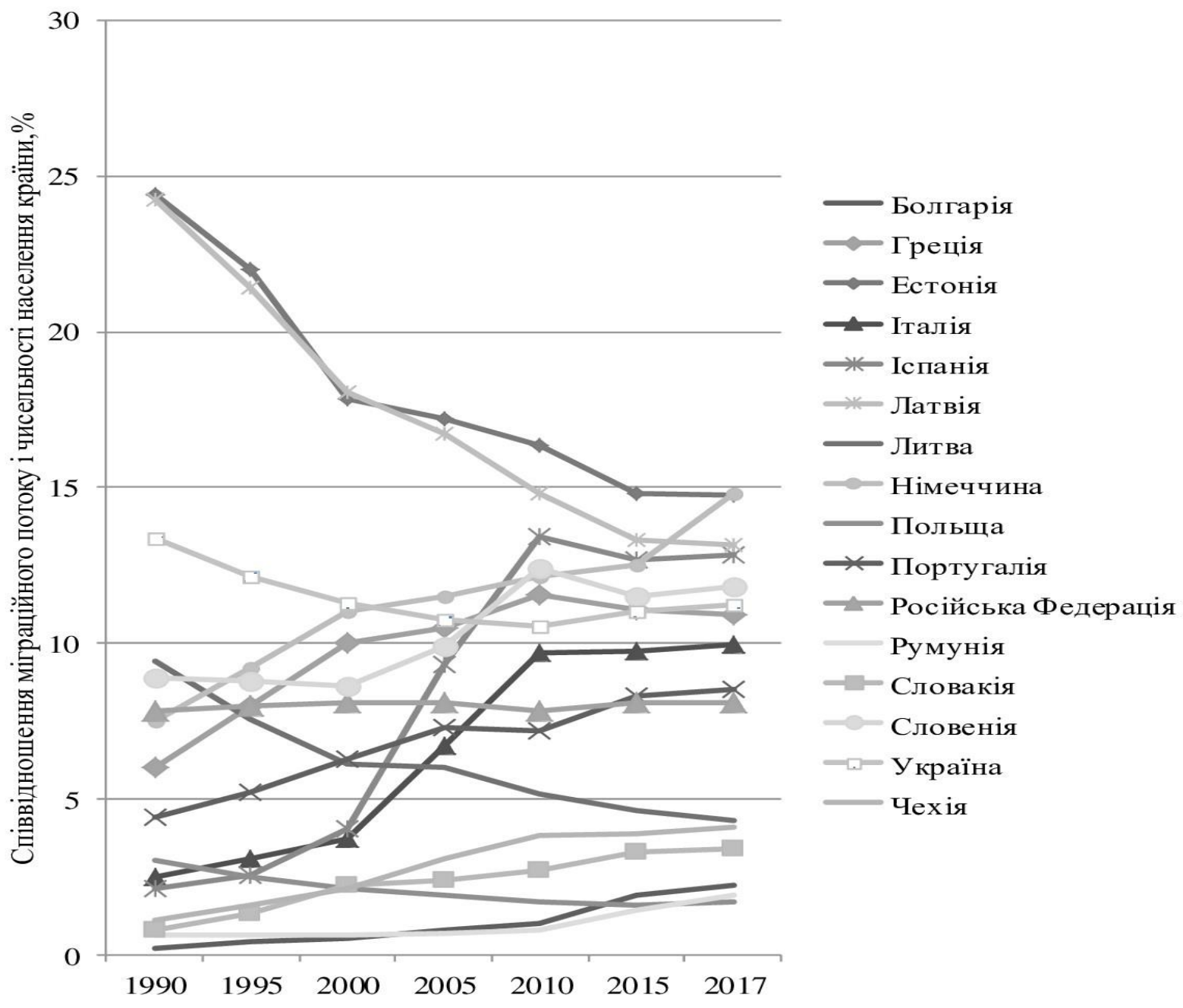

Рисунок 2 - Співвідношення міграційного потоку і чисельності населення України, країн Свропи і Російської Федерації

за 1990 - 2017 роки

Джерело: побудовано на підставі даних [17]

Серед досліджуваних країн (рис. 2) слід звернути увагу на тенденцію показника співвідношення міграційного потоку i чисельності населення Латвії і Естонії. Якщо у 90-ті роки ці країни демонстрували майже найвищий рівень цього показника - 24,2 і 24,4 відповідно, то розрахунок темпу змін у 2017 рік у порівнянні з 1990 роком показав зменшення міграційного потоку до чисельності населення на 45,5\% у Латвії і 39,7\% у Естонії.

До країн з подібною тенденцію слід віднести Литву (зменшення співвідношення міграційного потоку і численності населення на 45,3\% у 2017 р. у порівнянні з 1990 роком), Польщу (43,3\%). В Україні тем зміни був менше $(16,4 \%)$, але також спостерігається тенденція падіння значення показника співвідношення міграційного потоку до населення країни. 
Більшість досліджуваних країн демонструє зростання зазначеного показника. Найбільший темп зростання спостерігається у Іспанії і Італії, якщо у 1990 році показник по країнам мав значення 2,1 і 2,5, то у 2017 році він дорівнює 12,8 і 10,0 відповідно. У Німеччини співвідношення міграційного потоку і чисельності населення у 1990 році було 7,5, у 2017 році - 14,8.

Вітчизняні і зарубіжні науковці, розглядаючи проблему міграції, одним із основних економічних факторів називають рівень податкового навантаження. Розглянемо податкове навантаження макрорівня досліджуваних країнах (рис. 3). За загальноприйнятою методикою податкове навантаження на макрорівні визначається співвідношенням суми податків і ВВП.

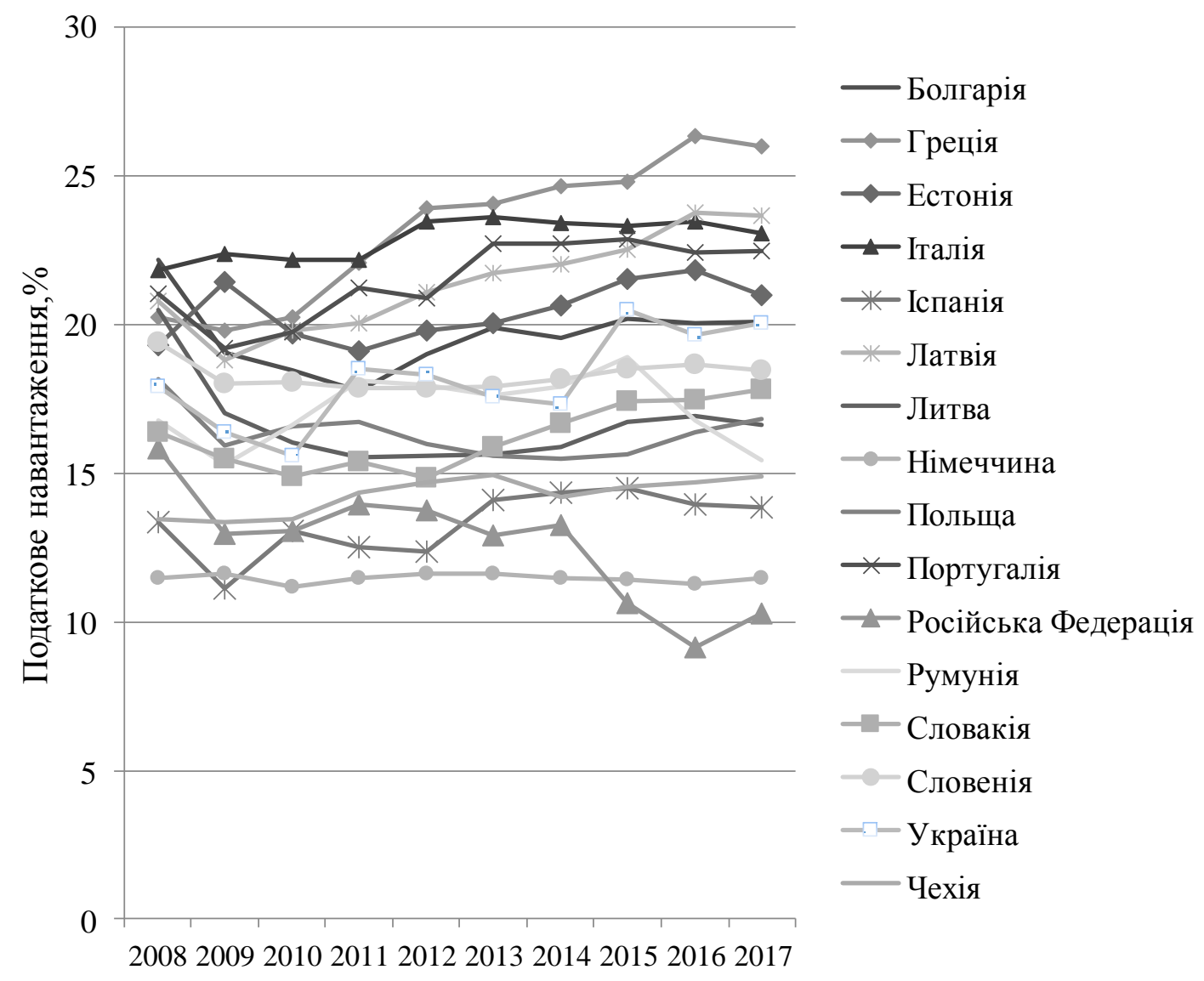

Рисунок 3 - Динаміка податкового навантаження на макрорівні України, країн Свропи і Російської Федерації за 2008 - 2017 роки Джерело: побудовано на підставі даних [18]

Серед представлених країн (рис. 3) найвищі показники податкового навантаження на макрорівні спостерігаються у Греції (діапазон коливань від 20,1\% у 2008 році до $25,9 \%$ у 2017 році), Італії (діапазон коливань від $21,8 \%$ у 2008 році до $23,1 \%$ у 2017 році), 
Португалії (діапазон коливань від 21,0\% у 2008 році до 22,5\% у 2017 році) і Латвії (діапазон коливань від 20,8\% у 2008 році до 23,6\% у 2017 році).

Одні з найнижчих значень податкового навантаження макрорівня спостерігаються у Німеччини: значення коливаються в межах 11,2 $11,6 \%$. Низькі значення показника у порівнянні 3 іншими країнами мають Чеська Республіка: діапазон коливань відсотка податків по відношенню до ВВП від 13,4\% у 2008 році 14,9\% у 2017 році, Російська Федерація: діапазон коливань від $15,8 \%$ у 2008 році до $10,3 \%$ у 2017 році.

Щодо України, то спостерігаються періоди, як зниження, так і зростання податкового навантаження. 32008 по 2010 рік відсоток податків по відношенню до ВВП зменшився з 17,9\% до 15,6\%, з 2012 по 2014 рік з 18,3\% до 17,3\%. Останні три роки рівень податкового навантаження зростав і складав $20,5 \%$ у 2015 році, $19,6 \%$ у 2016 році і $20,0 \%$ у 2017.

Для повноти дослідження розглянемо взаємозалежність показника чисельності мігрантів і рівня податкового навантаження. Для проведення розрахунків нами обрано дані за 2017 рік по досліджуваним країнам за чисельністю мігрантів i показником податкового навантаження (рис. 4).

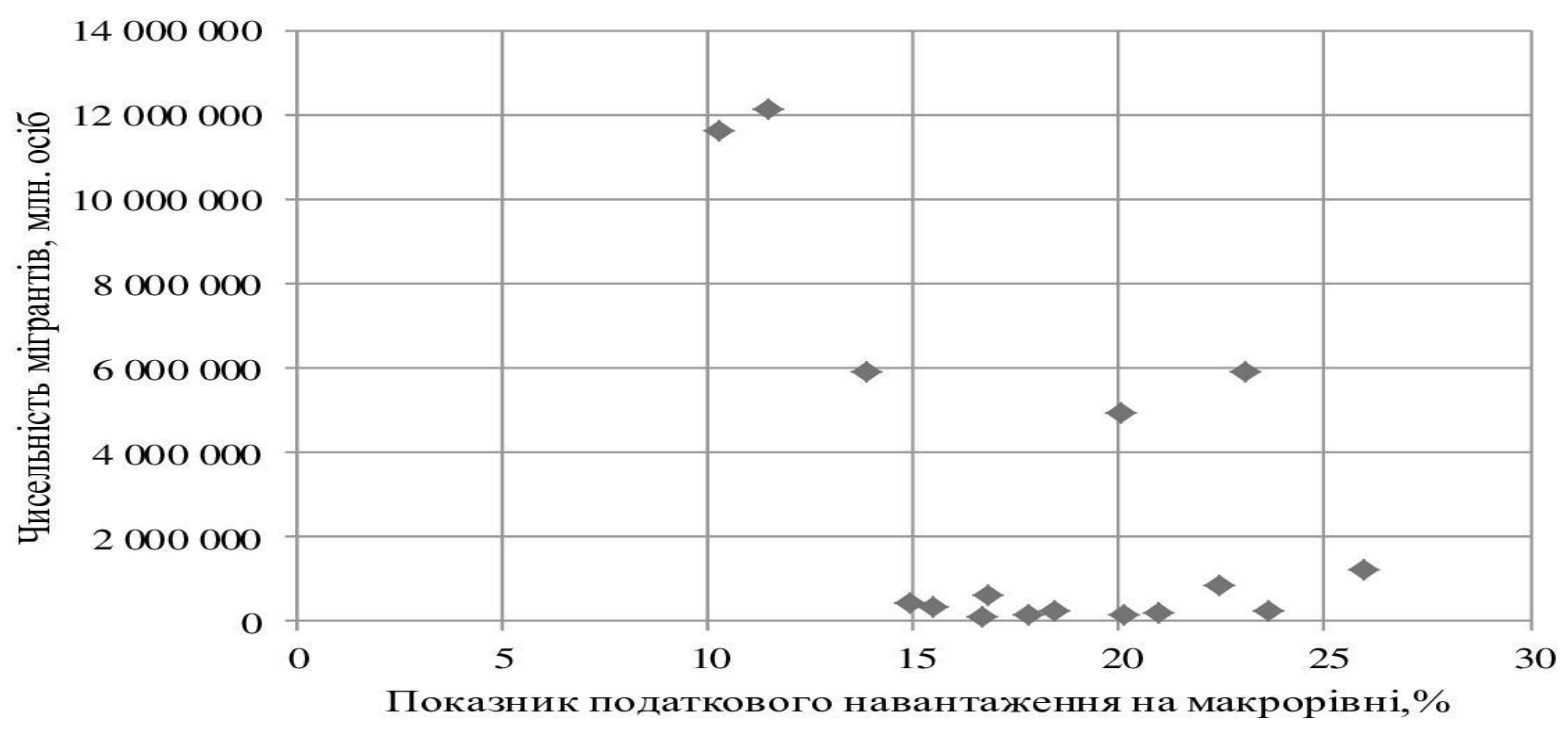

Рисунок 4 - Залежність чисельності мігрантів від показника податкового навантаження на макрорівні за 2017 р. Джерело: побудовано на підставі [17; 18]

Як видно з (рис. 4) в країнах, що були обрані для аналізу при податковому навантаженні до $10-13 \%$ спостерігається висока кількість мігрантів (бажаючих жити та працювати в цих країнах), а ті 
країни, що мали податковий тягар 25\% і більше, кількість мігрантів коливається на значеннях від 10000 до 150000 осіб.

В загальному вигляді функція, що описує залежність чисельності мігрантів від показника податкового навантаження на макрорівні, має вигляд:

$$
Y=f(t),
$$

Де, $\mathrm{Y}$ - теоретичний рівень ряду;

$t$ - змінна часу.

Як видно 3 табл.1, представлені типи моделей свідчать, що найвищі значення коефіцієнта апроксимації має поліноміальна $\left(R^{2}=0,6639\right)$ модель. Зазначена модель найбільш достовірно описує залежність показника чисельності мігрантів від співвідношення податків і ВВП країни.

Таблиця 1 - Моделі регресії та коефіцієнт апроксимації для прогнозування чисельності мігрантів від показника податкового навантаження

\begin{tabular}{|l|l|l|}
\hline \multicolumn{1}{|c|}{ Тип моделі } & \multicolumn{1}{c|}{ Рівняння } & \multicolumn{1}{c|}{ Коефіціснт апроксимації } \\
\hline Експоненціальна & $y=9 E+06 e^{-0,125 x}$ & $R^{2}=0,1164$ \\
\hline Лінійна & $y=-513354 x+1 E+07$ & $R^{2}=0,3085$ \\
\hline Логарифмічна & $y=-1 E+07 \ln (x)+3 E+07$ & $R^{2}=0,4063$ \\
\hline Поліноміальна & $y=117550 x^{2}-5 E+06 x+5 E+07$ & $R^{2}=0,6639$ \\
\hline Ступенева & $y=2 E+09 x^{-2,638}$ & $R^{2}=0,773$ \\
\hline
\end{tabular}

Джерело: складено авторами

Використовуючи дані поліноміальної моделі 3 (табл. 1), розглянемо, як зміна податкового навантаження впливатиме на чисельність мігрантів.

Переформатована для проведення розрахунків поліноміальна модель залежності чисельності мігрантів від показника податкового навантаження представлена на рис. 5.

Як зазначено вище (рис. 5), рівень податкового навантаження в Україні коливається від 15,6\% до 20,5\%. 


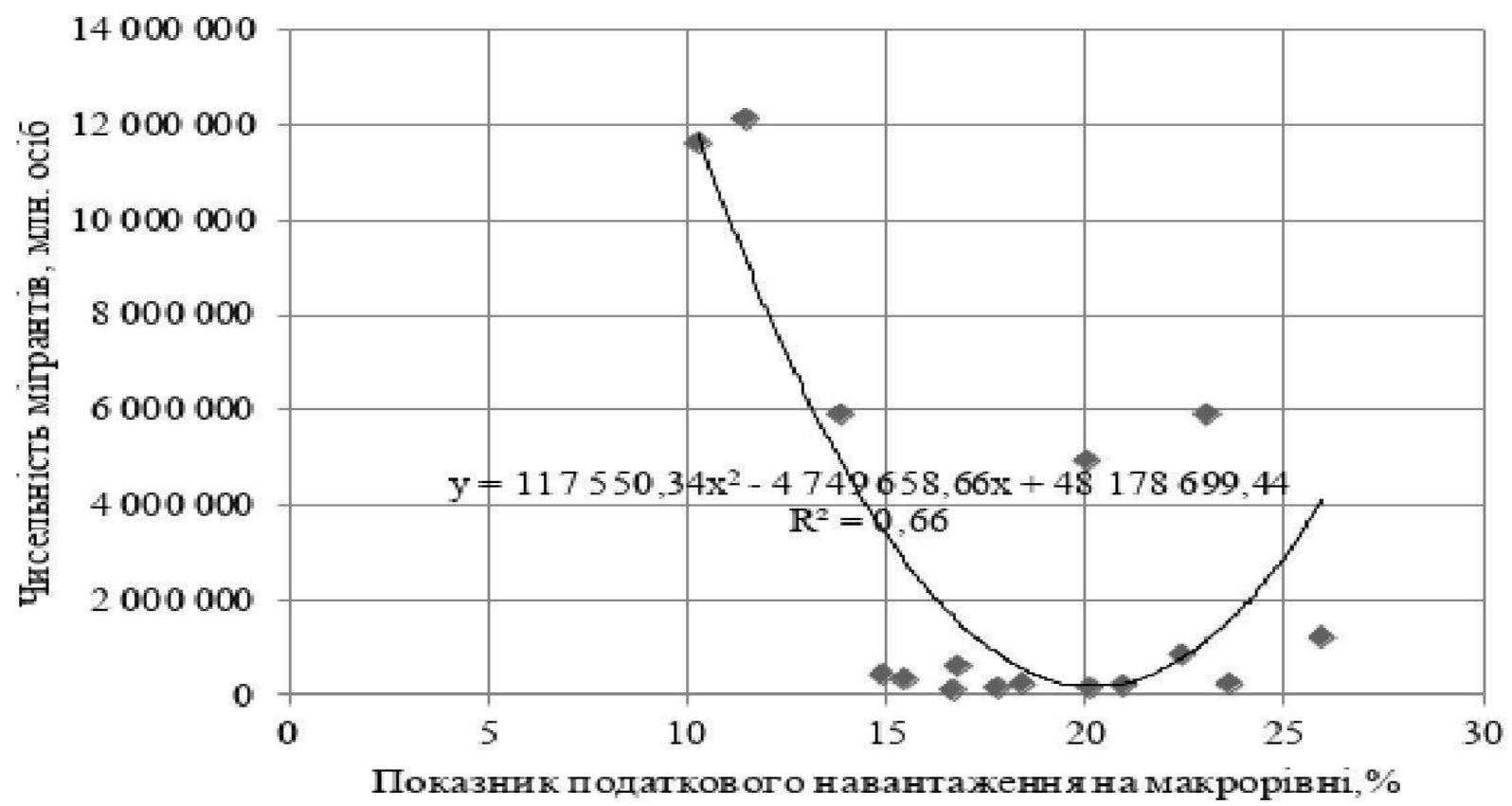

Рисунок 5 - Поліноміальна модель залежності чисельності мігрантів від податкового навантаження

Джерело: побудовано авторами

Таблиця 2 - Прогноз чисельності мігрантів при зміні податкового навантаження в Україні

\begin{tabular}{|c|c|}
\hline Прогнозні дані показника податкового навантаження, $\%$ & Чисельність мігрантів, осіб \\
\hline 12 & 8110044 \\
\hline 13 & 6299144 \\
\hline 14 & 4723344 \\
\hline 21 & 275568 \\
\hline 22 & 580573 \\
\hline 23 & 1120680 \\
\hline
\end{tabular}

Джерело: побудовано авторами

Розраховані прогнозні значення (табл. 2) свідчать, що найнижчий рівень чисельності мігрантів очікується при значенні податкового навантаження рівні $21 \%$, найвищий - за умов збільшення показника податкового навантаження до $23 \%$. Все це спровокує відтік більшої кількості працівників з України. Різниця зарплат (після оподаткування) між країною-донором та країнами-реципієнтами залишатиметься надзвичайно великою. Наприклад, за вже наявними даними, навіть мінімальна оплата праці в Польщі 31 січня 2020 року становить 2600 
злотих, або близько €690 чи 17 тис. грн за поточним курсом, у Чехії 13350 крон (€525 чи 16,5 тис. грн), у Словаччині - $€ 580$. У Литві мінімальна зарплата - €555, або 17,0 тис. грн., а в Естонії - €675 (ці виплати не оподатковуються), а це приблизно 21,5 тис. грн за поточним курсом гривні. В Україні мінімальна оплата праці з 2020 року - 4,729 тис. грн. чи це $€ 179$ (до вирахування податків), і навіть середня зарплата в абсолютній більшості регіонів країни поступатиметься показникам мінімальної, в сусідніх державах. Отже, така різниця у вартості праці (та податкового тягаря) й далі «виштовхуватиме» українців із українського ринку праці до країн Свросоюзу.

Мігранти допомагають заповнювати нестачу робочої сили у секторах інформаційних технологій, інженерії, туризму, освіти, охорони здоров'я, сільського господарства. Ці сектори економіки набули чітких ознак залежності від іммігрантів, крім того, таку ситуацію вже не доцільно розглядати, як нестійкий прояв $[13 ; 14 ; 16]$. Серед сприятливих наслідків процесу міграції вчені К. О. Демьяненко і М. О. Кримова виокремлюють наступні [3, с. 178]:

- пожвавлення притоку іноземної валюти, що позитивно впливає на загальну економічну ситуацію;

- ріст експортних можливостей для українських виробників та розширення можливостей торгового партнерства між країнами;

- акумуляція людського потенціалу такими особами, які перетинають кордон власної країни та, згодом, все ж повертаються у свою державу (такі громадяни здобувають новий досвід, як життєвий так і професійний, розширюють власний світогляд та, часто, схильні підвищувати рівень знання іноземної мови, мови країни, у якій цей час перебували);

- послаблення рівня напруги на національному ринку праці за рахунок відтоку частини безробітного населення за кордон, однак, вказаний фактор може приймати і негативний характер, оскільки, часто трапляється, що залишає кордон власної країни саме найбільш конкурентоспроможна і освічена робоча сила;

- накопичений мігрантами стартовий капітал часто знаходить своє втілення у спробах підприємницької діяльності - провадженні діяльності малих та середніх підприємств, які виникають після повернення мігрантів на Батьківщину, що, у свою чергу, каталізує у середині країни процеси розвитку підприємницької активності та створює сприятливі умови для формування середнього класу населення;

- можливість для мігрантів приймати участь в «етнічній економіці» країни, яка ії приймає, з орієнтацією на споживання українських товарів за кордоном; 
- стимул до виникнення спільних підприємств, а також, підвищення обсягу обміну товарами між країнами - експортером та імпортером людського капіталу.

Враховуючи перелік позитивних наслідків процесів міграції, можна відмітити таку особливість, що трудова міграція для громадян будь-якої країни відіграє роль дієвого засобу до працевлаштування, отримання гарантованого доходу, їх власної самореалізації, що, у свою чергу, створює сприятливі умови до включенню країни-реципієнта до світового ринку праці, формування середнього класу населення, а також є каталізатором інтеграції до світової спільноти [4, с. 369]. Трудові мігранти сприяють розвитку підприємництва, а отже, створюють робочі місця не лише для власних потреб, а і додаткові робочі місця для своїх співгромадян. Хоча, слід зазначити, що ефекти від грошових надходжень мігрантів не є однозначним, таку тенденцію відмічає і О.Ф. Дубовий. Так, грошові перекази мігрантів, часто спрямовані більшою мірою на задоволення споживчих потреб, а отже, здатні призводити до підвищення рівня імпорту, цін та інфляції у країні-донора [4, с. 370].

Крім цього, грошові перекази стають додатковим мотивом для збільшення трудової еміграції, тому розвиток економіки країни-донора може гальмуватися внаслідок дефіциту робочої сили $[7,10]$. Серед намірів працювати за кордоном, кваліфіковані молоді фахівці з вищою освітою називають: низькі перспективи майбутнього працевлаштування в Україні (72\%), рівень оплати праці не відповідає потребам і очікуванням (44\%), високе податкове навантаження (20 - 22\%) відсутність можливостей для повноцінної реалізації професійних якостей (41\%), нестабільну політичну ситуацію (34\%) [2, с. 71;17;18]. Основними факторами, що сформували характер зовнішньої трудової міграції з України, стали такі події, як анексія Російською Федерацією Автономної Республіки Крим, військові дії на територіях Донбасу, що прямо вплинуло на стан інвестиційного клімату у бік його зниження та суттєвого скорочення виробництва. Скорочення промислового виробництва, зниження рівня i якості життя населення України спричинили зростання масштабів міжнародної трудової міграції. Іншим фактором, який вплинув на цей процес, можна назвати наростаюча цікавість деяких країн європи, наприклад, Польщі та Чехії, яка стала причиною розширення міграційних квот i спрощення процесу працевлаштування. Пропозиції роботи цих країн стали привабливішими для українців, ніж шукати заробіток на Батьківщині, що призвело до неможливості адаптуватися до зростаючих вимог якості підготовки фахівців, зниження зацікавленості роботодавців у спеціалістах певних професій, надмірна кількість підготовлених вузами 
фахівців окремих спеціальностей обумовили пошуки некваліфікованої роботи поза межами України.

Аналізуючи сучасний стан зазначених процесів в Україні, можна помітити, що йому притаманний активний міграційний рух населення, збільшується кількість випадків прибуття і вибуття та міграційний приріст. Це означає, що продовжується ще одна (п'ята) хвиля еміграції [15], яка характеризується зростанням масштабів зовнішньої трудової міграції та формування потоків вимушеної міграції.

Також перетин кордону українцями у пошуках роботи став зручнішим за рахунок введення безвізового режиму з країнами, що входять до складу ЄС. Це створило передумови для зміни напряму зовнішньої трудової міграції зі скороченням потоку трудових мігрантів до Російської Федерації і зростанням кількості тих, хто виїжджав у пошуках роботи до країн $\mathrm{CC}$.

Основними проблемами регулювання міграції, які уповільнюють процес співробітництва між Україною та країнами СС та мають негативні соціально-економічні наслідки є такі, як:

- відсутність дієвого та узгодженого механізму, яких націлений на запобігання правопорушень, які трапляються у сфері перебігу процесів міграції;

- недосконалий механізм запобігання виникненню нелегальної міграції та роботи з нелегальними мігрантами;

- недостатньо розвинена законодавча база, у тому числі відсутність міжнародних угод про працевлаштування у європейських країнах $(\mathrm{CC})$;

- відтік коштів із країни шляхом переводу фінансових трансфертів трудовими мігрантами на Батьківщину;

- втрата висококваліфікованих трудових ресурсів, так званий “відтік мізків".

Висновки. Проведене дослідження надало можливість встановити чітку взаємозалежність та визначити рівень впливу оподаткування на регулювання міжнародної трудової міграції. Для реалізації мети дослідження і вирішення проблемних питань авторами запропоновано обрати країни, попередньо розділивши їх на дві групи згідно рівня їх привабливості для міграції робочої сили, i рівнозначності показника ВВП. Згідно запропонованої логіки побудовано діаграми динаміки співвідношення міграційного потоку i чисельності населення та динаміки податкового навантаження на макрорівні за встановлений період у групах країн. За результатами встановлено, що повноту дослідження відображають дані про рівень податкового навантаження макрорівня досліджуваних країн та його взаємозалежність з показником чисельності мігрантів. 
Наукова новизна одержаних результатів полягає у встановленні чіткої взаємозалежності проілюстрованої у вигляді математичної моделі, яка має форму регресії та коефіцієнту апроксимації для прогнозування чисельності мігрантів від показника податкового навантаження. Модель достовірно описує залежність показника чисельності мігрантів від співвідношення податків і ВВП країни. Розраховані прогнозні значення свідчать, що найнижчий рівень чисельності мігрантів очікується при значенні податкового навантаження рівні 21\%, найвищий - за умов збільшення показника податкового навантаження до $23 \%$.

Практичне значення одержаних результатів полягає у застосуванні запропонованої моделі, що обумовлене необхідністю пошуку оптимальних шляхів зменшення негативного впливу процесів міжнародної трудової міграції на рівень економічного та соціального розвитку країни.

Перспективним напрямом подальших досліджень $\epsilon$ імплементація запропонованої авторами моделі у політику соціального та економічного розвитку країни, що прямо впливатиме на рівень та якість міграційного потоку.

\section{Література:}

1. Аналітична записка. Скільки українців поїхало за кордон і що державі з цим робити URL: https://ces.org.ua/wp-content/uploads/2018/04/Migration-note.pdf (дата звернення 02.06.2019)

2. Ангелко І. Соціально-економічні наслідки міжнародної міграції робочої сили на добробут населення України. Вісник Тернопільського національного економічного університету. 2014. № 4. С. 65-72.

3. Демьяненко К.О., Кримова М.О. Наслідки та причини активізації трудової міграції в Україні. Вісник студентського наукового товариства Донецького національного університету імені Василя Стуса. 2018. №10. С. 175-179.

4. Дубовий О.Ф. Феномен сучасної української трудової міграції та його соціальноекономічні наслідки. Науковий вісник Національного лісотехнічного університету України. 2011. №8. С. 368-372.

5. Звіт щодо методології, організації проведення та результатів вибіркового модульного дослідження з питань трудової міграції в Україні. Міжнародна організація праці, Державна служба статистики України URL: http://www.ilo.org/wcmsp5/groups/public/europe/rogeneva/srobudapest/documents/pu blication/wcms_244746.pdf. (дата звернення 30.05.2019)

6. Зовнішні трудові міграції населення України : монографія / за наук. ред. Е. Лібанової, О. Позняка. Київ: РВПС України, 2002. 104 с.

7. Ионцев В. Каменский А. Международная миграция населения в России. Международная миграция: молодежный выпуск / за ред. В.А. Ионцев. Москва, 2005. № 13. С. 10-11.

8. Корчемаха Е. На работу за рубеж. Как гастарбайтеры меняют экономику Украины и мира URL: https://www.unian.net/economics/finance/10061717-narabotu-za-rubezh-kak-gastarbaytery-menyayut-ekonomiku-ukrainy-i-mira.html (дата звернення 31.05.2019) 
9. Курунова Ю.О. Міжнародна міграція робочої сили як чинник економічного розвитку країн (на прикладі міграційних потоків між СС і Україною): дис. канд. екон. наук: 08.00.02. Одеса, 2015. 172 с.

10. Перерахунок даних щодо приватних грошових переказів в Україну за 2015 - 2017 роки. Національний банк України. URL: https://bank.gov.ua/doccatalog/document?id=66364144 (дата звернення 02.06.2019)

11. Пробоїв О. А. Напрями подолання міграційної кризи в країнах СС i врегулювання потоків нелегальної міграції [Електронний ресурс]: Економіка і суспільство. 2017. Вип. 8 URL: http://economyandsociety.in.ua/ journal/8_ukr/15.pdf (дата звернення 30.05.2019)

12. Castles S., Miller M. J. The age of migration: International population movements in the Modern World. L; Basingstone: Macmillan, 1993. London. 306 p.

13. Guardia N. D. Labour Migration Patterns in Europe: Recent Trends, Future Challenges. European Commission. DirectorateGeneral for Economic and Financial Affairs. 2006. № 256. 52 p.

14. Massey D. S. Patterns and Processes of International Migration in the 21st Century . USA : University of Pennsylvania. 2003. 42 p.

15. Nyberg Sorensen N. The development dimension of Migrants Transfers. Danish Institute for International Studies. Copenhagen, 2005. P. 6.

16. Solimano A. Globalization, history and international migration: a view from Latin America. Commission on the Social Dimension of Globalization, Policy Integration Department, 2004. Paper № 37.33 p.

17. International migrant stock: The 2017 revision. Total international migrant stock / International Organization for migration. URL: http://www.un.org/en/development/desa/population/migration/data/index.asp.(accesse d 25 March 2019).

18. Tax revenue / The World Bank (2014). URL: https://data.worldbank.org/indicator/GC.TAX.TOTL.GD.ZS (accessed 25.02.2020).

\section{References:}

1. Centre for economic strategy (2018), Skil'ky ukraintsiv poikhalo za kordon i scho derzhavi z tsym robyty. Analitychna zapyska [How many Ukrainians went abroad and what should the state do about it. Analytical note], available at: https://ces.org.ua/wpcontent/uploads/2018/04/Migration-note.pdf (Accessed 02 June 2019).

2. Angelko, I. (2014), «Socio-economic consequences of international labor migration for the welfare of the population of Ukraine», Herald of Ternopil National Economic University, vol. 4, pp. 65-72.

3. Demyanenko, K. O., Krimova, M. O. (2018), «Consequences and reasons for the intensification of labor migration in Ukraine», Bulletin of the Student Scientific Society of Vasyl Stus Donetsk National University, vol. 10, pp. 175-179.

4. Dubovy, O. F. (2011), The phenomenon of modern Ukrainian labor migration and its socio-economic consequences, Scientific Bulletin of UNFU, vol. 8, pp. 368-372.

5. International Labor Organization, State Statistics Service of Ukraine (2013), Zvit schodo metodolohii, orhanizatsii provedennia ta rezul'tativ vybirkovoho modul'noho doslidzhennia z pytan' trudovoi mihratsii v Ukraini [Report on the Methodology, Organization and Results of a Modular Sample Survey on Labour Migration in Ukraine], available at: http://www.ilo.org/wcmsp5/groups/public/---europe/---ro- 
geneva/---sro-budapest/documents/publication/wcms_244746.pdf (Accessed 30 May 2019).

6. Libanova, E., Poznyak, O. (2002), Zovnishni trudovi mihratsii naselennia Ukrainy : monohrafiia [External labor migration of the population of Ukraine: monograph], Kiev, Ukraine.

7. Iontsev, V. Kamenskiy, A. (2005), International population migration in Russia. International migration: youth edition, vol. 13, pp. 10-11.

8. Korchemaha, E. (2018), To work abroad. How guest workers are changing the economy of Ukraine and the world, available at: https://www.unian.net/economics/finance/10061717-na-rabotu-za-rubezh-kakgastarbaytery-menyayut-ekonomiku-ukrainy-i-mira.html (Accessed 31 May 2019).

9. Kurunova, Yu.O. (2015), International labor migration as a factor of economic development of countries (on the example of migration flows between the EU and Ukraine), Abstract of Ph.D. dissertation, Global economy and International Economic Relations, Odessa I. I. Mechnikov National University, Odessa, Ukraine.

10. National Bank of Ukraine (2018), Pererakhunok danykh schodo pryvatnykh hroshovykh perekaziv v Ukrainu za 2015 - 2017 roky [Recalculation of data on private remittances to Ukraine for 2015 - 2017], available at: file://C:/Users/lenovo/Downloads/remittances\%20_pererahun_2015-2017.pdf (Accessed 06 June 2019).

11. Proboev, O. A. (2017), Directions for overcoming the migration crisis in the EU and regulating the flow of illegal migration, Economy and society, vol. 8, available at: http://economyandsociety.in.ua/ journal/8_ukr/15.pdf (Accessed 30 May 2019).

12. Castles, S., Miller, M. J. (1993), The age of migration: International population movements in the Modern World, Macmillan, London, UK.

13. Guardia, N. D. (2006), Labour Migration Patterns in Europe: Recent Trends, Future Challenges. European Commission. Directorate General for Economic and Financial Affairs, vol. 256.

14. Massey, D. S. (2003), Patterns and Processes of International Migration in the 21st Century, University of Pennsylvania, USA.

15. Nyberg Sorensen, N. (2005), The development dimension of Migrants Transfers, Danish Institute for International Studies, Copenhagen, pp. 6.

16. Solimano, A. (2004), Globalization, history and international migration: a view from Latin America. Commission on the Social Dimension of Globalization, Policy Integration Department, vol. 37, pp. 33.

17. International Organization for migration (2017), International migrant stock: The 2017 revision. Total international migrant stock, available at: http://www.un.org/en/development/desa/population/migration/data/index.asp. (Accessed 25 March 2019).

18. The World Bank (2014), Tax revenue, available at: https://data.worldbank.org/indicator/GC.TAX.TOTL.GD.ZS (Accessed 25.02.2020). 